\title{
Coincidence of an anterior cerebral artery aneurysm and a glioblastoma: case report and review of literature
}

This article was published in the following Dove Press journal:

International Medical Case Reports Journal

25 November 2015

Number of times this article has been viewed

\author{
Ha Son Nguyen' \\ Ninh Doan' \\ Michael Gelsomino' \\ Saman Shabani' \\ Wade Mueller' \\ Osama O Zaidat ${ }^{2}$ \\ 'Department of Neurosurgery, \\ ${ }^{2}$ Department of Neurology, \\ Medical College of Wisconsin, \\ Milwaukee, WI, USA
}

Correspondence: Ha Son Nguyen Department of Neurosurgery, Medical College of Wisconsin, 9200 West Wisconsin Avenue, Milwaukee, WI 53226, USA

Tel +l 4|48055400

Email hsnguyen@mcw.edu
Background: The association between glioblastoma and intracranial aneurysm is rare. Treatment guidelines do not exist, and operative mortality and morbidity are significantly high. To our knowledge, no prior cases have employed endovascular therapy for the treatment of these intratumor intracranial aneurysms followed by tumor resection.

Case presentation: A 74-year-old male, history of a left A2 aneurysm, presented after a motor vehicle accident at low speeds. Imaging was concerning for a possible traumatic brain contusion, an aneurysmal hemorrhage given history of left A2 aneurysm, or a hemorrhage from an underlying tumor given profound edema. The patient was discussed at the brain tumor board, where the plan was to address the aneurysm followed by resection of the mass versus close monitoring with subsequent imaging. The high risk of rehemorrhage, given the real possibility of an aneurysmal hemorrhage, motivated prompt treatment of the aneurysm. The patient was taken to the angiography suite; an anterosuperiorly projecting azygous A2 aneurysm, measuring $4.5 \mathrm{~mm} \times 5.5 \mathrm{~mm}$ with a neck width at $3.5 \mathrm{~mm}$ and a small daughter sac, was completely obliterated with primary coiling. The following day, he underwent a left craniotomy along a forehead skin crease for mass excision. Final pathology revealed glioblastoma. The patient recovered well from both procedures, with a baseline neurological exam. The patient subsequently underwent hypofractionated radiation and temodar.

Conclusion: To our knowledge, no prior cases have employed endovascular therapy for the treatment of these intracranial aneurysms. We emphasize that efforts to introduce less invasive elements may improve the overall outcomes in this rare patient population.

Keywords: intracranial aneurysm, glioblastoma, traumatic brain injury

\section{Introduction}

The association between intracranial tumor and aneurysm is uncommon. Reported incidence has ranged between $0.3 \%$ and $4 \% .{ }^{1-4}$ The subset that involves glioblastoma is rare. Cases from literature have been organized into three general categories: ${ }^{5}$ 1) simultaneous discovery of both pathologies, ${ }^{1,3,6-11} 2$ 2) development of glioblastoma after the treatment of aneurysm, ${ }^{12,13}$ and 3) development of aneurysm after treatment of glioblastoma. ${ }^{1,5}$ The actual incidence of this association may be higher, since angiography is seldom completed for brain tumors. ${ }^{5}$ Intracranial aneurysms may arise at a location remote to the glioblastoma in some instances, ${ }^{5,8}$ while in others they may be anatomically close to the tumor. ${ }^{7,10}$

Overall, the operative mortality for patients with a brain tumor and a cerebral aneurysm is significantly high, close to $40 \%$. $^{2}$ For patients with dual pathologies, no clear guidelines exist. Past treatment strategies have varied, but have mainly emphasized 
a combination of aneurysm clipping and tumor debulking. To our knowledge, there have been no cases that employed a staged approach, consisting of endovascular intervention and followed by tumor excision. We report such a scenario, where the initial presentation also involved a traumatic brain injury, which further complicated the treatment strategy. Moreover, we review the literature regarding patients with dual pathologies.

\section{Case report}

A 74-year-old male, history of a left A2 aneurysm, presented after a motor vehicle accident at low speeds. At the scene, the patient exhibited confusion. He sustained abrasions above his left eye, around his nose, and above his lip. Upon further investigation, patient had also had a syncopal episode on the prior day, where he fell and hit his head as well. Besides the confusion, he exhibited no focal neurological deficits. A computed tomography (CT) head demonstrated a $4 \mathrm{~cm} \times 6 \mathrm{~cm}$ hyperdensity and edema with mass effect on left frontal area (Figure 1). The concerns included possible traumatic brain contusion, aneurysmal hemorrhage (given history of left A2 aneurysm), or hemorrhage from an underlying tumor given profound edema. The patient was started on fosphenytoin. A CT angiography of the head demonstrated a pericallosal cerebral aneurysm (Figure 2A). A magnetic resonance imaging of the brain demonstrated a bifrontal, enhancing brain lesion with surrounding edema, concerning for a high-grade glioma (Figure 3A and B). Subsequently, he was started on intravenous decadron.

The patient was discussed at the brain tumor board, where the plan was to address the aneurysm followed by resection of the mass versus close monitoring with subsequent imaging. The high risk of rehemorrhage, given the possibility of an aneurysmal hemorrhage, motivated prompt treatment of the aneurysm. The patient was taken to the angiography suite. An anterosuperiorly projecting azygous A2 aneurysm,

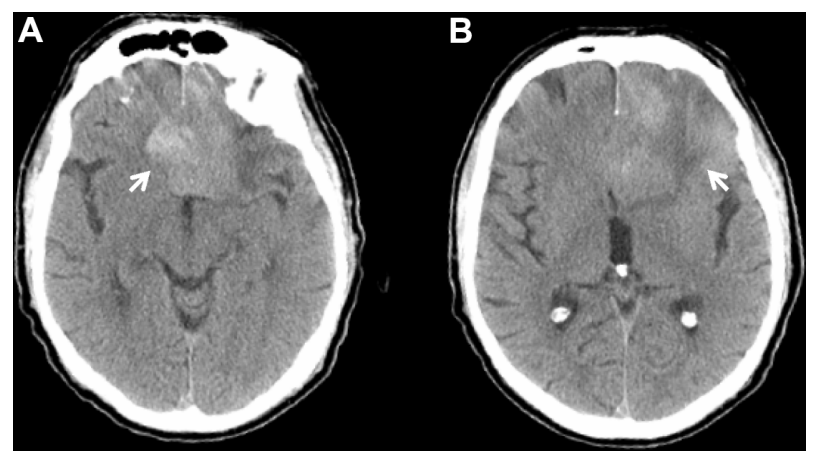

Figure I Axial CT demonstrates midline hyperdensity (arrow; A), and left frontal surrounding hypodensity (arrow; B).

Abbreviation: CT, computed tomography. measuring $4.5 \mathrm{~mm} \times 5.5 \mathrm{~mm}$ with a neck width at $3.5 \mathrm{~mm}$ and a small daughter sac, was completely obliterated with primary coiling (Figure $2 \mathrm{~B}$ and $\mathrm{C}$ ). Visualization of the external carotid arteries and internal carotid arteries bilaterally did not show any tumor blush. The following day, he underwent a left craniotomy along a forehead skin crease for mass excision. Final pathology revealed glioblastoma. The patient recovered well from both procedures, with a baseline neurological exam. The patient subsequently underwent hypofractionated radiation and temodar. The Medical College of Wisconsin does not require Institutional Review Board approval or patient consent for this case study.

\section{Discussion}

For patients with an intracranial tumor and an aneurysm, Pia et $\mathrm{al}^{2}$ noted that $69 \%$ of cases exhibited initial symptoms attributed to the tumor, while $22 \%$ exhibited symptoms consistent with the aneurysm, and 6\% demonstrated symptoms associated with both pathologies. Our patient presented after a traumatic brain injury, but the history of recent confusion prior to his car accident insinuates the effects from the frontal mass and surrounding edema.

The etiology of hemorrhage in our patient remains unclear. CT head was consistent with intralesional hemorrhage. Moreover, there may be a component of traumatic brain injury given his physical findings and mechanism of injury. Glioblastoma has a recognized tendency for intratumoral hemorrhage. ${ }^{14-18}$ However, presentation with subarachnoid hemorrhage is infrequent, with reported incidences ranging between $1.4 \%$ and $4.9 \% .^{19,20}$ Based on the ISUIA study, the A2 aneurysm in our patient has a low risk of hemorrhage, given its location along the anterior circulation and its relatively small size; ${ }^{21}$ on the other hand, the presence of a daughter sac may increase the risk for hemorrhage..$^{22,23}$ Overall, there was a significant concern that the hyperdensity represented aneurysmal hemorrhage, which prompted treatment of the existing aneurysm given risks for rehemorrhage.

The pathogenesis for intracranial aneurysm in the presence of glioblastoma has been debated. One theory involves the alteration in flow dynamics; ${ }^{5}$ aneurysms may be linked to the arteries that supply glioblastomas; pathological lowresistance vessels that result in arteriovenous shunting are present in glioblastomas; an increase in flow may augment hemodynamic stress and contribute to the development of an aneurysm, not unlike the pathogenesis of aneurysms within arteriovenous malformations. ${ }^{5,10}$ Another notion suggests that tumor invasion of blood vessels may lead to development of an aneurysm. Glioblastoma is characterized 


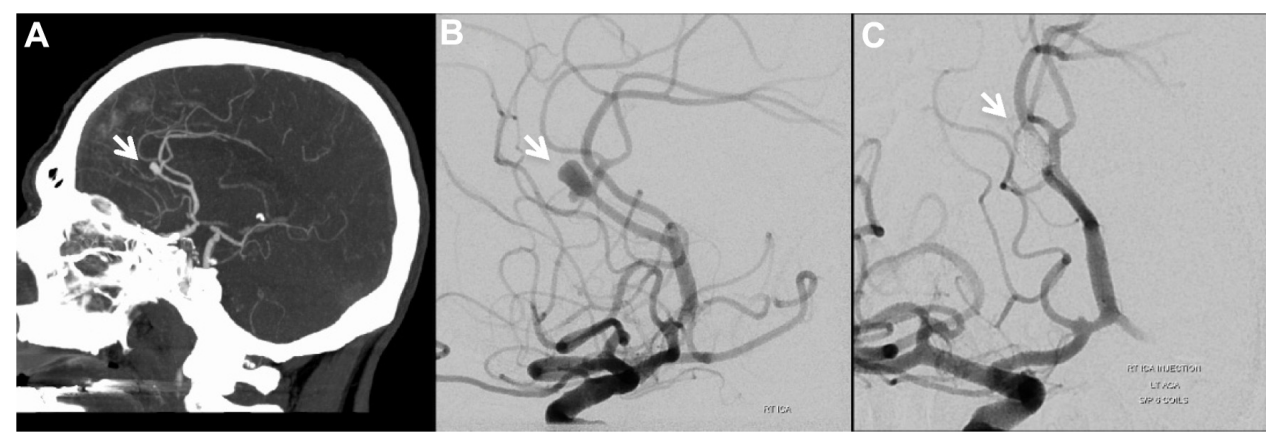

Figure 2 (A) Sagittal CT head angiography demonstrates A2 aneurysm (arrow). Diagnostic subtraction angiography (B) and (C) exhibit complete occlusion of A2 aneurysm after primary coiling (arrows).

Abbreviation: CT, computed tomography.

by endothelial proliferation, necrosis, telangiectasia, and fibrosis of adjacent blood vessels. ${ }^{6,24}$ Andrews et al ${ }^{6}$ discovered glial fibrillary acidic protein staining within the walls of aneurysm that was associated with a glioblastoma. Moreover, Aoki et $\mathrm{al}^{7}$ described a dissection of the middle cerebral artery by tumor cells; similarly, Cowen et al ${ }^{24}$ noted fusiform dilatation of pericallosal arteries caused by infiltration of tumor cells.

For aneurysms that develop after the treatment of glioblastoma, radiation may also play a role in pathogenesis. ${ }^{5,10,25}$ Radiation may cause vasculopathy, characterized by endothelial damage that progresses to inflammation, thrombosis, intimal narrowing, and atherosclerosis. ${ }^{25}$ These histological alterations, which predominantly influence the media and the intima, may lead to fragile points along blood vessels that are prone for aneurysmal formation. ${ }^{25}$ Brachytherapy, whole brain radiation, and stereotactic radiosurgery have all been implicated with the development of intracranial aneurysms. ${ }^{25}$

Table 1 highlights the English literature regarding cases with simultaneous presentation of a glioblastoma and an

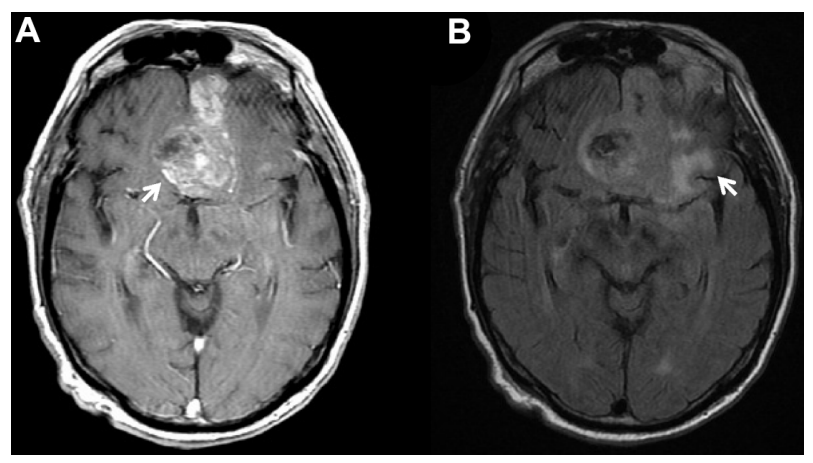

Figure 3 (A) Axial MR TI with contrast demonstrates heterogeneously enhancing lesion along midline and left frontal area (arrow). (B) Axial MR FLAIR demonstrates perilesional edema (arrow).

Abbreviations: MR TI, TI-weighted image magnetic resonance; MR FLAIR, magnetic resonance-fluid-attenuated inversion recovery. intracranial aneurysm. Several cases involve a 1-stage approach where both are treated (Cases 6, 9, 11, 13, and 15). A few cases involved a 2-stage approach (Cases 1, 8, and 10); however, Case 10 involved a postoperative hemorrhage from a previously undiagnosed anterior communicating artery aneurysm that necessitated a second surgery while Case 8 involved a glioblastoma that was undiagnosed until pathology of the aneurysm and surrounding tissue had resulted. Details were unclear regarding a 1-stage or 2-stage approach in Cases 4 and 5. In Cases 7, 14, and 16, the pathologies were discovered at different times, and as such were treated in a "staged" fashion. Surgical treatment of the aneurysms includes clipping, muscle wrapping, resection, and vessel sacrifice. Our case involved a 2-stage approach, which entailed primary coiling of the A2 aneurysm, followed by excision of the tumor. No cases have detailed this type of approach. The operative mortality of patients with the association of a brain tumor and an intracranial aneurysm is significantly high. Besides the concern for intraoperative aneurysmal rupture, there have been instances of postoperative hemorrhage if the aneurysm was not addressed. ${ }^{1,26}$ Although employment of endovascular therapy entails an additional procedure, the opportunity to introduce a less invasive element may help reduce morbidity and mortality in such cases. As in our case, if there is a concern of aneurysmal rupture and subsequent risk for rehemorrhage, we recommend therapy be directed at the aneurysm first. Open surgical treatment directed at the aneurysm would lead to significant alteration of the tumor anatomy and margin and would hinder subsequent tumor resection effort. Alternatively, performing tumor resection first without securing the aneurysm would risk the rerupture of the aneurysm during the case, a source of morbidity and mortality. This report proposes a definitive treatment regimen addressing both the tumor and the aneurysm with good outcomes. This treatment regimen should be an option for patients suspected to have these dual pathologies. 
Table I Available English literature review

\begin{tabular}{|c|c|c|c|c|c|c|c|c|}
\hline Cases & Literature & Age & Sex & Presentation & $\begin{array}{l}\text { Tumor } \\
\text { location }\end{array}$ & $\begin{array}{l}\text { Aneurysm } \\
\text { location }\end{array}$ & Approach & Outcome \\
\hline 1 & Taylor et al' & 33 & $M$ & $\begin{array}{l}\text { Focal seizures, left side } \\
\text { weakness, headaches }\end{array}$ & $R$ frontal & R ACA & $\begin{array}{l}\text { Tumor resection, post operative } \\
\text { SAH from right A2 aneurysm, } \\
\text { reoperation for trapping of aneurysm }\end{array}$ & Death \\
\hline 2 & Pia et $\mathrm{al}^{2}$ & 32 & $* * *$ & Tumor symptoms & $\mathrm{L}$ parietal & L ICA & $\begin{array}{l}\text { Tumor resection, no treatment for } \\
\text { aneurysm }\end{array}$ & Good \\
\hline 3 & Pia et $\mathrm{al}^{2}$ & 55 & $M$ & $\begin{array}{l}\text { Subarachnoid } \\
\text { hemorrhage }\end{array}$ & $\mathrm{R}$ parietal & R Pcomm & $\begin{array}{l}\text { Tumor resection; aneurysm } \\
\text { thrombosed }\end{array}$ & Death \\
\hline 4 & $\begin{array}{l}\text { Obrador } \\
\text { et } \mathrm{al}^{2}\end{array}$ & 54 & $M$ & Tumor symptoms & $\begin{array}{l}\text { L temporo- } \\
\text { occipital }\end{array}$ & ? AcoA & $\begin{array}{l}\text { Unclear I or } 2 \text { stage; tumor } \\
\text { resection and aneurysm clipping } \\
\text { occurred }\end{array}$ & Good \\
\hline 5 & Pia et $\mathrm{al}^{2}$ & $* * *$ & $* * *$ & Tumor symptoms & ? MCA & $* * *$ & $\begin{array}{l}\text { Unclear I or } 2 \text { stage; tumor resection } \\
\text { and aneurysm clipping occurred }\end{array}$ & Good \\
\hline 6 & Honda et $\mathrm{al}^{3}$ & 59 & $\mathrm{~F}$ & $\begin{array}{l}\text { Right spastic hemiparesis } \\
\text { and motor aphasia }\end{array}$ & $L$ temporal & L AcoA & $\begin{array}{l}\text { I stage: aneurysm clipping, followed } \\
\text { by tumor resection }\end{array}$ & Good \\
\hline 7 & Yoon et $\mathrm{al}^{5}$ & 57 & $M$ & $\begin{array}{l}\text { Headache and memory } \\
\text { difficulty }\end{array}$ & $R$ frontal & R ACA & $\begin{array}{l}2 \text { stage: tumor resection, followed } \\
\text { by aneurysm clipping }\end{array}$ & Good \\
\hline 8 & $\begin{array}{l}\text { Andrews } \\
\text { et al }{ }^{6}\end{array}$ & 53 & $\mathrm{~F}$ & $\begin{array}{l}\text { Sudden headaches, } \\
\text { lethargy, meningismus }\end{array}$ & $\begin{array}{l}\text { L frontal } \\
\text { temporal }\end{array}$ & L M2 & $\begin{array}{l}2 \text { stage: aneurysm resection with } \\
\text { weck clips, tumor resection }\end{array}$ & No data \\
\hline 9 & Aoki et $\mathrm{al}^{7}$ & 57 & $M$ & $\begin{array}{l}\text { Acute onset left } \\
\text { hemiplegia, dysarthria }\end{array}$ & $\begin{array}{l}\mathrm{R} \text { frontal } \\
\text { temporal }\end{array}$ & L MCA & $\begin{array}{l}\text { I stage: resection of mass, sacrifice } \\
\text { of } \mathrm{MI}\end{array}$ & Good \\
\hline 10 & $\begin{array}{l}\text { Cheng and } \\
\text { Shen }^{8}\end{array}$ & 67 & $\mathrm{~F}$ & $\begin{array}{l}\text { Right hemiparesis and } \\
\text { aphasia }\end{array}$ & $\mathrm{L}$ parietal & L ICA & $\begin{array}{l}2 \text { stage: aneurysm clipped via } \\
\text { keyhole approach, followed by } \\
\text { tumor resection I week later }\end{array}$ & Good \\
\hline II & Gokalp et al ${ }^{9}$ & 50 & $M$ & Visual disturbances & Bifrontal & L ACA & $\begin{array}{l}\text { I stage: conservative resection, then } \\
\text { clipping }\end{array}$ & Death \\
\hline 12 & $\begin{array}{l}\text { Hashiguichi } \\
\text { et al }{ }^{10}\end{array}$ & 44 & $\mathrm{~F}$ & $\begin{array}{l}\text { Recurrent GBM, } \\
\text { disabled, bedridden }\end{array}$ & $L$ frontal & $\begin{array}{l}\text { Tumor } \\
\text { feeding vessel }\end{array}$ & No surgery & Vegetative \\
\hline 13 & Paoletti et al" & 59 & M & Confusion, emesis & $L$ frontal & L MCA & $\begin{array}{l}\text { Radiation/CCNU } \\
\text { I stage: late resection, then clipping }\end{array}$ & Good \\
\hline 14 & $\begin{array}{l}\text { De Chiara } \\
\text { et al }{ }^{12}\end{array}$ & 52 & $\mathrm{~F}$ & $\begin{array}{l}\text { Headaches and neck } \\
\text { pain }\end{array}$ & $\mathrm{R}$ temporal & R ICA & $\begin{array}{l}2 \text { stage: aneurysm clipping, followed } \\
\text { by tumor resection }\end{array}$ & Fair \\
\hline 15 & Cowen et $\mathrm{al}^{24}$ & 57 & M & $\begin{array}{l}\text { Headaches, dizziness, } \\
\text { hearing difficulty, } \\
\text { blurred vision }\end{array}$ & Bifrontal & $\begin{array}{l}\text { Pericallosal } \\
\text { arteries }\end{array}$ & $\begin{array}{l}\text { I stage: radical resection of tumor } \\
\text { and aneurysm }\end{array}$ & Good \\
\hline 16 & Ali et $\mathrm{al}^{27}$ & 63 & M & $\begin{array}{l}\text { Headaches, dizziness, } \\
\text { left hand ataxia }\end{array}$ & $\begin{array}{l}\mathrm{R} \text { fronto- } \\
\text { temporal }\end{array}$ & R MCA & $\begin{array}{l}2 \text { stage: tumor resection, followed } \\
\text { by aneurysm clipping }\end{array}$ & Death \\
\hline 17 & Present case & 74 & M & $\begin{array}{l}\text { Traumatic brain injury, } \\
\text { confusion }\end{array}$ & $L$ frontal & L A2 & $\begin{array}{l}2 \text { stage: primary coiling of aneurysm, } \\
\text { followed by tumor resection the } \\
\text { next day }\end{array}$ & Good \\
\hline
\end{tabular}

Notes: ***No available information. ? indicates the tumor/aneurysm location was not clear.

Abbreviations: M, male; F, female; L, left; R, right; ACA, anterior cerebral artery; ICA, internal carotid artery; MCA, middle cerebral artery; SAH, subarachnoid hemorrhage; GBM, glioblastoma; CCNU, I-[2-chloroethyl]-3-cyclohexyl-I-nitrosourea; Pcomm, posterior communicating artery; AcoA, anterior communicating artery.

\section{Conclusion}

The simultaneous presentation of a glioblastoma and an intracranial aneurysm is rare. Treatment guidelines do not exist, while operative mortality and morbidity is significantly high. To our knowledge, no prior cases have employed endovascular therapy for the treatment of these intracranial aneurysms. We emphasize that efforts to introduce less invasive elements may improve the overall outcomes in this rare patient population.

\section{Acknowledgment}

The research did not receive any funding from organizations or grants.

\section{Disclosure}

The authors report no conflicts of interest in this work.

\section{References}

1. Taylor PE. Delayed postoperative hemorrhage from intracranial aneurysm after craniotomy for tumor. Neurology. 1961;11:225-231.

2. Pia HW, Obrador S, Martin JG. Association of brain tumours and arterial intracranial aneurysms. Acta Neurochir (Wien). 1972;27: 189-204.

3. Honda M, Kamada K, Nakata Y, Harada T, Iwanaga H, Tsukamoto M. The association of cerebral aneurysm with malignant brain tumor - report of a case (author's transl). No Shinkei Geka. 1980;8:1065-1070.

4. Okamura T, Watanabe Y, Kameda H, Aoki H, Kurokawa K. Coexistence of brain tumors and cerebral aneurysms - clinical considerations from eight cases (author's trans1). Neurol Med Chir (Tokyo). 1981;21: 601-608. 
5. Yoon WS, Lee KS, Jeun SS, Hong YK. De novo aneurysm after treatment of glioblastoma. J Korean Neurosurg Soc. 2011;50:457-459.

6. Andrews BT, Raffel C, Rosegay H. Subarachnoid hemorrhage from a peripheral intracranial aneurysm associated with malignant glioma: report of a case. Neurosurgery. 1985;17:645-649.

7. Aoki N, Sakai T, Oikawa A, Takizawa T, Koike M. Dissection of the middle cerebral artery caused by invasion of malignant glioma presenting as acute onset of hemiplegia. Acta Neurochir (Wien). 1999;141: 1005-1008.

8. Cheng WY, Shen CC. Minimally invasive approaches to treat simultaneous occurrence of glioblastoma multiforme and intracranial aneurysm case report. Minim Invasive Neurosurg. 2004;47:181-185.

9. Gokalp HZ, Avman N, Ozkal E, Gokben B. Brain tumour associated with intracranial arterial aneurysm. Acta Neurochir (Wien). 1980;53: 267-273.

10. Hashiguchi A, Morioka M, Ichimura H, Mimata C, Kuratsu J. Glioblastoma with an intratumoral feeding-artery aneurysm. Clin Neurol Neurosurg. 2007;109:302-304.

11. Paoletti P, Rodriguez y Baena R, Sangiovanni G, Scelsi M. Association of a malignant glioma and an aneurysm of the middle cerebral artery. Report of a case. J Neurosurg Sci. 1983;27:211-217.

12. De Chiara A, Benvenuti D, Maiuri F, Giamundo A, Lavano A Association of internal carotid aneurysm and temporal glioblastoma. Neurochirurgia (Stuttg). 1986;29:58-60.

13. Licata C, Pasqualin A, Freschini A, Barone G, Da Pian R. Management of associated primary cerebral neoplasms and vascular malformations: 1. Intracranial aneurysms. Acta Neurochir (Wien). 1986;82:28-38.

14. Kim YJ, Lee SK, Cho MK, Kim YJ. Intraventricular glioblastoma multiforme with previous history of intracerebral hemorrhage: a case report. J Korean Neurosurg Soc. 2008;44:405-408.

15. Inamasu J, Kuramae $T$, Nakatsukasa M. Glioblastoma masquerading as a hypertensive putaminal hemorrhage: a diagnostic pitfall. Neurol Med Chir (Tokyo). 2009;49:427-429.

16. Lakicevic G, Arnautovic K, Muzevic D, Chesney T. Cerebellar glioblastoma multiforme presenting as hypertensive cerebellar hemorrhage: case report. J Neurol Surg Rep. 2014;75:e117-e121.
17. Wakai S, Yamakawa K, Manaka S, Takakura K. Spontaneous intracranial hemorrhage caused by brain tumor: its incidence and clinical significance. Neurosurgery. 1982;10:437-444.

18. Kondziolka D, Bernstein M, Resch L, et al. Significance of hemorrhage into brain tumors: clinicopathological study. J Neurosurg. 1987;67: $852-857$.

19. Glass B, Abbott KH. Subarachnoid hemorrhage consequent to intracranial tumors; review of literature and report of seven cases. AMA Arch Neurol Psychiatry. 1955;73:369-379.

20. Locksley HB, Sahs AL, Sandler R. Report on the cooperative study of intracranial aneurysms and subarachnoid hemorrhage. 3. Subarachnoid hemorrhage unrelated to intracranial aneurysm and $\mathrm{A}-\mathrm{V}$ malformation. A study of associated diseases and prognosis. $J$ Neurosurg. 1966;24: 1034-1056.

21. Wiebers DO, Whisnant JP, Huston J 3rd, et al. Unruptured intracranial aneurysms: natural history, clinical outcome, and risks of surgical and endovascular treatment. Lancet. 2003;362:103-110.

22. Matsukawa H, Uemura A, Fujii M, Kamo M, Takahashi O, Sumiyoshi S. Morphological and clinical risk factors for the rupture of anterior communicating artery aneurysms. J Neurosurg. 2013;118:978-983.

23. UCAS Japan Investigators, Morita A, Kirino T, et al. The natural course of unruptured cerebral aneurysms in a Japanese cohort. $N$ Eng J Med. 2012;366:2474-2482.

24. Cowen RL, Siqueira EB, George E. Angiographic demonstration of a glioma involving the wall of the anterior cerebral artery. Report of a case. Radiology. 1970;97:577-578.

25. Nanney AD 3rd, El Tecle NE, El Ahmadieh TY, et al. Intracranial aneurysms in previously irradiated fields: literature review and case report. World Neurosurg. 2014;81:511-519.

26. Yamada $\mathrm{H}$, Taomoto K. Postoperative subarachnoid hemorrhage from an intracranial aneurysm after craniotomy for astrocytoma - case report. Neurol Med Chir (Tokyo). 1989;29:846-849.

27. Ali R, Pabaney A, Robin A, Marin H, Rosenblum M. Glioblastoma and intracranial aneurysms: case report and review of literature. Surg Neurol Int. 2015;6:66
International Medical Case Reports Journal

\section{Publish your work in this journal}

The International Medical Case Reports Journal is an international, peer-reviewed open-access journal publishing original case reports from all medical specialties. Previously unpublished medical posters are also accepted relating to any area of clinical or preclinical science. Submissions should not normally exceed 2,000 words or

\section{Dovepress}

4 published pages including figures, diagrams and references. The manuscript management system is completely online and includes a very quick and fair peer-review system, which is all easy to use. Visit http://www.dovepress.com/testimonials.php to read real quotes from published authors. 